\title{
Secondary effluent purification by a large-scale multi-stage surface-flow constructed wetland: A case study in northern China
}

\author{
Haiming $\mathrm{Wu}^{\text {a }}$, Jian Zhang ${ }^{\mathrm{b}, *}$, Wenshan Guo ${ }^{\mathrm{c}}$, Shuang Liang ${ }^{\mathrm{b}}$, Jinlin Fan ${ }^{\mathrm{d}}$ \\ ${ }^{a}$ College of Natural Resources and Environment, Northwest A \& F University, Yangling, Shaanxi 712100, \\ PR China \\ ${ }^{b}$ Shandong Key Laboratory of Water Pollution Control and Resource Reuse, School of Environmental \\ Science \& Engineering, Shandong University, Jinan 250100, PR China \\ ${ }^{c}$ School of Civil and Environmental Engineering, University of Technology Sydney, Broadway, NSW \\ 2007, Australia \\ ${ }^{d}$ National Engineering Laboratory of Coal-Fired Pollutants Emission Reduction, Shandong University, \\ Jinan 250061, PR China \\ *Corresponding author. E-mail address: zhangjian00@sdu.edu.cn (J. Zhang).
}

\begin{abstract}
Assessment of treatment performance in the large-scale constructed wetland $(\mathrm{CW})$ for secondary effluent purification remains limited. The aim of this case study was to therefore to investigate the long-term treatment capacity of organics and ammonium pollutants in a large-scale multi-stage surface-flow (SF) CW fed with secondary effluents from the wastewater treatment plants (WWTPs) in northern China. The results for two-and-half-year study period indicated that the water quality parameters including chemical oxygen demand (COD) and ammonium $\left(\mathrm{NH}_{4}{ }^{+}-\mathrm{N}\right)$ met the Chinese Grade III of Environmental Quality Standards. The mass reductions of COD and $\mathrm{NH}_{4}{ }^{+}-\mathrm{N}$ were 53\% $\left(4032 \mathrm{~kg} \mathrm{ha}^{-1} \mathrm{y}^{-1}\right)$ and $72 \%\left(511 \mathrm{~kg} \mathrm{ha}^{-1} \mathrm{y}^{-1}\right)$, respectively. However, there was a significant positive correlation between influent loads and treatment performance. The optimal loading of $2.5 \mathrm{~g} \mathrm{~m}^{-2} \mathrm{~d}^{-1}$ for COD and $0.3 \mathrm{~g} \mathrm{~m}^{-2} \mathrm{~d}^{-1}$ for $\mathrm{NH}_{4}{ }^{+}-\mathrm{N}$ could be recommended for designing the sustainable large-scale multi-stage SF CW wastewater treatments.
\end{abstract}

Keywords: Secondary effluent; Surface flow constructed wetlands; Water quality; Organics removal; Nitrogen removal

\section{Introduction}

Nowadays, when facing the rising demand for clean water, the treatment capacity and effluent quality is still relatively low even though the majority of existing WWTPs including various centralized and decentralized systems have been developed in developing countries (Wu et al., 2016a,b). Moreover, the standard limits for effluent quality and surface water quality are becoming much stricter in order to satisfy the growing environmental legislation (He and Xue, 2010; Rai et al., 2013; Wu et al., 2016a; Zhang et al., 2017). Therefore, some eco-sustainable treatment technologies after sewage treatment would be an alternative and economical option for secondary effluent purification.

Constructed wetlands (CWs), as a typical ecologically based wastewater treatment system with less constructing and operating costs, have been attracted more attention especially in rural and remote regions in developing countries (Wu et al., 2015a,b; Vivant et al., 2016). Numerous previous 
studies have shown that CWs, depending on their configurations and characteristics, can deal with a wide range of wastewaters including domestic sewage, agricultural wastewater, industrial effluent, mine drainage, landfill leachate, urban runoff and polluted river water (Matamoros et al., 2008; Saeed and Sun, 2012; Verlicchi and Zambello, 2014; Wu et al., 2016a; Li et al., 2017). Currently, given their low cost and broad adaptability, CWs have been also used to treat WWTP effluents which might be discharged directly into natural aquatic environments (rivers, lakes, oceans, wetlands). Several studies reported that CWs can efficiently reduce organic and inorganic pollutants as well as harmful pathogens from WWTP effluents, and could effectively improve the water quality and restore river ecological environment (Wang et al., 2012; Chen et al., 2014; Wu et al., 2016c; Vivant et al., 2016). However, most of those studies were performed in microcosmscale or pilot-scale CW systems with a small area, and few studies exist on purifying secondary effluent by using a full-scale or large-scale CW system. Matamoros et al. (2008) studied the removal of a variety of organic pollutants in a full-scale surface flow (SF) CW treating conventional WWTP secondary effluent discharged into the River Besos of northeastern Spain, and indicated that CW was efficient for removing 12 organic micropollutants from WWTP effluent. Avila et al. (2015) studied the treatment capacity of a multi-stage CW system as a supplementary to conventional WWTP. Their results demonstrated an excellent elimination of conventional water quality parameters, and proved that the final effluent could comply with existing Spanish regulations for various reuse applications (Avila et al., 2015). Moreover, a recent study of using SF CWs for treating effluent from a WWTP by Vivant et al. (2016) reported that SF CWs could be an efficient system to limit the dissemination of fecal contamination to the aquatic environment, but vegetated areas of the $\mathrm{CW}$ during the warmer months reduced the efficiency of the SF CW. So far, not enough data are currently available on the long-term treatment efficiency of the large-scale CWs for removing organic and nitrogen pollutants from secondary effluent of WWTPs.

The aim of this study was therefore to investigate the long-term treatment capacity of a large-scale multi-stage SF CW system for purifying secondary effluents from the conventional WWTPs in northern China. The specific objectives were to: (i) evaluate the removal performance of organics and ammonium pollutants in the large-scale multi-stage SF CW operated for more than two years; (ii) determine the sustainability of the $\mathrm{CW}$ system in water quality improvement to meet the environmental quality standards in China; (iii) explore the effect of input loading on the removal efficiency in the large-scale CW system.

\section{Materials and methods}

\subsection{Site description}

This study was carried out in a large-scale CW system (namely Wu River CW) situated in Linyi,

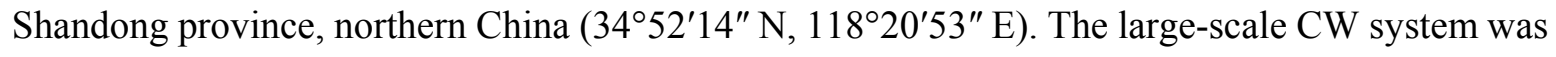
designed as a purification system to treat the secondary effluent from the municipal WWTPs (400,000 equivalent inhabitants). The climate condition of this area is a warm temperate continental monsoon climate with a mean annual temperature and an average annual precipitation of $13.4{ }^{\circ} \mathrm{C}$ and $840.1 \mathrm{~mm}$, respectively. Average seasonal air temperatures during the experimental period are spring (from March to May) $7.5^{\circ} \mathrm{C}$, summer (from June to September) $24.5^{\circ} \mathrm{C}$ and fall (from October to November) $19.1{ }^{\circ} \mathrm{C}$, winter (from December to February) $2.7^{\circ} \mathrm{C}$. 


\subsection{Constructed wetland design}

The Wu River large-scale CW was designed in a multi-stage SF CW style and it was mainly composed of a rubber dam, a distribution ditch, a detention pond, seven stages of SF CWs, and several overflow weirs. The schematic diagram of the $\mathrm{Wu}$ River large-scale $\mathrm{CW}$ is given in the Supporting Information. The large-scale system was constructed in 2010 to polish on average $3.8 \times 10^{5} \mathrm{~m}^{3}$ day $^{-1}$ of secondary effluent from municipal WWTPs, and the total available land area of the system was about $86.6 \times 10^{5} \mathrm{~m}^{2}$. The substrate of CW system was the natural soil of the Wu River and held a $0.3-0.5 \mathrm{~m}$ depth of water. Theoretical hydraulic retention time (HRT) was 7 day with an average hydraulic loading rate (HLR) of $0.035 \mathrm{~m} \mathrm{day}^{-1}$. In the SF CWs, several native wetland plant species were planted, including Phragmites australis (P. australis), Typha orientalis (T. orientalis), Zizania latifolia (Z. latifolia), Nelumbo nucifera (N. nucifera), Nymphaea tetragona (N. tetragona), Potamogeton crispus (P. crispus), Lemna minor (L. minor) and water hyacinth. During the long-term experiment from July 2011 to December 2013, average influent concentrations of chemical oxygen demand (COD) and ammonium $\left(\mathrm{NH}_{4}^{+}-\mathrm{N}\right)$ were $45.3 \mathrm{mg} \mathrm{L}^{-1}$ and $4.5 \mathrm{mg} \mathrm{L}^{-1}$. The effluent from the $\mathrm{Wu}$ River large-scale $\mathrm{CW}$, which was discharged into a river named Yi River, was designed to meet the Grade III of Chinese Environmental Quality Standards for Surface Water (GB3838-2002). That is, the purified effluent should not exceed the permitted limits of COD $20 \mathrm{mg} \mathrm{L}^{-1}$ and $\mathrm{NH}_{4}^{+}-\mathrm{N} 1 \mathrm{mg} \mathrm{L}^{-1}$, respectively. The water quality and removal performance of the $\mathrm{Wu}$ River large-scale $\mathrm{CW}$ are described in the Supporting Information.

\subsection{Water sampling and monitoring}

During the whole experimental period, water samples were collected at the inlet and the outlet of the Wu River large-scale CW once or twice a day (a total of 1000 times between July 2011 and December 2013. All the collected samples were kept refrigerated and transferred immediately to the laboratory. Then they were stored at $4{ }^{\circ} \mathrm{C}$ until chemical analysis. The parameters analyzed mainly included COD and $\mathrm{NH}_{4}{ }^{+}-\mathrm{N}$. Unfiltered water samples were used directly in COD analysis, while water samples for $\mathrm{NH}_{4}{ }^{+}-\mathrm{N}$ were filtered through glass microfiber filters. All of these analyses were performed according to standard laboratory procedures and methods (APHA, 2005).

\subsection{Calculations and statistics}

In order to evaluate the removal performance of COD and $\mathrm{NH}_{4}{ }^{+}-\mathrm{N}$ in the $\mathrm{Wu}$ River large-scale $\mathrm{CW}$, removal efficiency (rate) was calculated as follows:

$$
\begin{aligned}
& \text { Removal efficiency }(\%)=\frac{\left(C_{i} Q_{i}-C_{e} Q_{e}\right)}{C_{i} Q_{i}} \times 100 \\
& \text { Removal rate }\left(\mathrm{g} \mathrm{m}^{-2} \mathrm{~d}^{-1}\right)=q \times\left(\mathrm{C}_{\mathrm{i}}-\mathrm{C}_{\mathrm{e}}\right)
\end{aligned}
$$

where $C_{i}$ Influent pollutant concentration $\left(\mathrm{mg} \mathrm{L}^{-1}\right) ; C_{e}$ Effluent pollutant concentration $\left(\mathrm{mg} \mathrm{L}^{-1}\right)$; $Q_{i}$ Daily volumetric water influent flow rate $\left(\mathrm{m}^{3}\right.$ day $\left.^{-1}\right)$; $Q_{e}$ Daily volumetric water effluent flow rate $\left(\mathrm{m}^{3}\right.$ day $\left.^{-1}\right) ; q$ Hydraulic loading rate $\left(\mathrm{m} \mathrm{day}^{-1}\right)$.

All statistical analyses were performed by using the statistical program SPSS 11.0 (SPSS Inc., Chicago, USA). Two-sample $t$-test and one-factor analysis of variance were used for the compare 
the differences between means. In all tests, differences and correlations were considered statistically significant when $\mathrm{P}<.05$.

\section{Results and discussion}

\subsection{Long-term performance assessment of the large-scale system}

\subsubsection{Organics removal}

Long-term monitoring data from July 2011 to December 2013 were analyzed to assess the overall removal performance of the Wu River large-scale CW system. The COD concentrations, removal efficiency and annual removal rates in the Wu River large-scale CW system over the whole period are presented in Fig. 1a. Seemingly, a significant removal for COD from the Wu River large-scale $\mathrm{CW}$ was obtained. The average effluent COD concentration in the $\mathrm{Wu}$ River large-scale $\mathrm{CW}$ was $20 \mathrm{mg} \mathrm{L}^{-1}$, which can apparently comply with the Grade III $\left(20 \mathrm{mg} \mathrm{L}^{-1}\right)$ of Environmental Quality Standards for Surface Water (GB3838-2002) in China. Accordingly, the average removal efficiency was $53 \%$ for COD with the annual removal rate of $4032 \mathrm{~kg} \mathrm{ha}^{-1} \mathrm{y}^{-1}$. However, as shown by the minimum and maximum values in the COD concentrations and removal efficiency, a clear seasonal variation of COD removal was observed in the Wu River large-scale CW system. In the warmer seasons, the average removal efficiency was over $65 \%$ (from May to July), while an obvious decrease to below $40 \%$ was found in the colder seasons (November and December). This could be mainly due to variations in environmental factors such as average air temperatures which can vary between $2.7^{\circ} \mathrm{C}$ (winter) and $24.5^{\circ} \mathrm{C}$ (summer) during the experimental period. These results in this study are in conformity with those values obtained by Jia et al. (2014) in the fourstage CW system for treating polluted water from an urban river. Furthermore, it is generally accepted that CWs can treat wastewater within an optimal load capacity range, and out of range or changes in hydraulic loading will affect the oxygen environment and the removal processes of organic pollutants in CWs (Rai et al., 2013; Saeed and Sun, 2012; Wu et al., 2015a). Therefore, some alternative preventive measures and enhancing strategies such as insulation measurements, decreasing hydraulic loading, psychrotrophic bacteria addition, and seasonal plant collocation should be considered to improve wastewater treatment efficiency of CWs at low temperature in the future full-scale application (Wu et al., 2015b; Zhang et al., 2017).

\subsubsection{Ammonium removal}

The level of effluent $\mathrm{NH}_{4}{ }^{+}-\mathrm{N}$ is another major indicator for evaluating the water purification effect of the Wu River large-scale CW system because the effluent from the CW system would directly flow into the Yi River which is the main environmental monitoring section for surface water in China. Fig. $1 \mathrm{~b}$ shows the $\mathrm{NH}_{4}{ }^{+}-\mathrm{N}$ concentrations, removal efficiency and annual removal rates in the Wu River large-scale CW system during the whole period which indicating an effective and high reduction for $\mathrm{NH}_{4}{ }^{+}-\mathrm{N}$ from secondary effluent of WWTPs. The average effluent $\mathrm{NH}_{4}{ }^{+}-\mathrm{N}$ concentration in the Wu River large-scale $\mathrm{CW}$ was $1.1 \mathrm{mg} \mathrm{L}^{-1}$, which basically meets the Grade III standard ( $\left.1 \mathrm{mg} \mathrm{L}^{-1}\right)$, according to the Chinese Environmental Quality Standards for Surface Water (GB3838-2002). The average removal efficiency and the annual removal rate of $\mathrm{NH}_{4}{ }^{+}-\mathrm{N}$ were $72 \%$ and $511 \mathrm{~kg} \mathrm{ha}^{-1} \mathrm{y}^{-1}$, respectively. This removal rate is essentially in agreement with the values (72\%) reported by Avila et al. (2015) in a full-scale three stages CW system $\left(786 \mathrm{~m}^{2}\right)$ for wastewater treatment and reuse in the Mediterranean area. While the removal rate is higher than 
that $(62 \%)$ obtained in a full-scale hybrid CW (1000 population equivalent) treating municipal wastewater in Italy (Barco and Borin Maurizio, 2017).
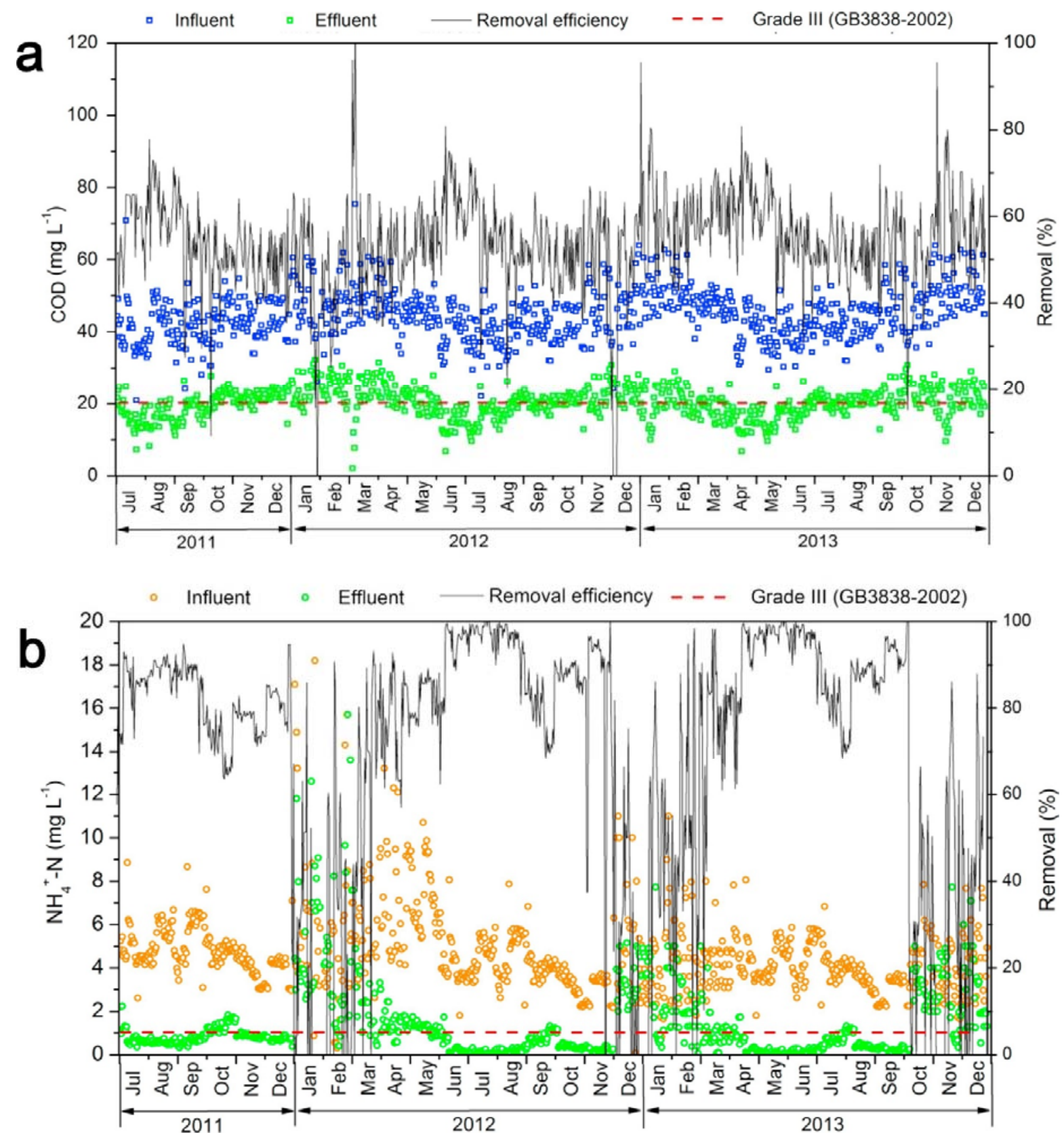

Fig. 1. Variation of COD and $\mathrm{NH}_{4}{ }^{+}-\mathrm{N}$ removal performance of the $\mathrm{Wu}$ River multi-stage constructed wetland during the long-term operating period (2011-2013).

However, a similar fluctuating trend to COD removal was observed for $\mathrm{NH}_{4}{ }^{+}-\mathrm{N}$ removal in the $\mathrm{Wu}$ River large-scale CW in the long-term monitoring period. The $\mathrm{NH}_{4}{ }^{+}-\mathrm{N}$ removal efficiency of the large-scale CW varied significantly by season. In warmer seasons (from March to September), temperatures were higher, and wetland plants and microorganisms grew well. As a result, the average removal efficiency for $\mathrm{NH}_{4}{ }^{+}-\mathrm{N}$ was more than $80 \%$. On the contrary, in colder seasons (in early Spring and Winter), there was a reduction of less than $30 \%$ in $\mathrm{NH}_{4}^{+}-\mathrm{N}$ removal efficiency. 
The main possible reason can be that lower air temperatures in colder environment may restrain wetland plant growth and microbial activity, which can decrease $\mathrm{NH}_{4}{ }^{+}-\mathrm{N}$ removal (Saeed and Sun, 2012; Jia et al., 2014; Andreo-Martínez, et al., 2017). Moreover, the release of nutrients from decomposing wetland vegetation, which is inevitable due to plant senescence, should be noted in $\mathrm{CW}$ wastewater treatments ( $\mathrm{Wu}$ et al., 2015b). Therefore, in order to gain the effective and sustainable pollutant removal performance in full-scale CW projects, plant harvesting strategies including times of harvest and the density of harvested biomass in cold climatic conditions are indispensable.

\subsection{Influence of input loading on removal rate}

Generally, complete organics and nitrogen removal processes in SF CWs are mainly accomplished by the aerobic, anaerobic and heterotrophic microbial process, which could be generally influenced by various environmental and operational conditions such as such as: temperature, loading rate, retention time (Saeed and Sun, 2012; Fan et al., 2013; Wu et al., 2015a). Particularly, inflow loading rate is one of the important designing and operating parameters in CWs and plays a key role in optimizing the treatment performance of CWs. To provide some recommendations on the design and operation of $\mathrm{CW}$ wastewater treatments for a broader application, the impact of input loading variations on the long-term removal performance of the Wu River large-scale CW system was investigated (in Fig. 2). It is shown that average loading rates were $1.9 \mathrm{~g} \mathrm{~m}^{-2} \mathrm{~d}^{-1}$ for COD and $0.2 \mathrm{~g} \mathrm{~m}^{-2} \mathrm{~d}^{-1}$ for $\mathrm{NH}_{4}{ }^{+}-\mathrm{N}$. Removal rates of COD and $\mathrm{NH}_{4}{ }^{+}-\mathrm{N}$ from the large-scale $\mathrm{CW}$ increased with increases of influent loading rates. In addition, based on a linear regression analysis conducted with all of the monitoring data, a strong positive correlation was found between removal rates and influent loads for COD $\left(\mathrm{R}^{2}=0.92, \mathrm{p}<.01\right)$, but a weak correlation was observed between $\mathrm{NH}_{4}{ }^{+}-\mathrm{N}$ removal and input loading $\left(\mathrm{R}^{2}=0.45, \mathrm{p}<.01\right)$. Specially, when influent COD load rate was ranging between 1.5 and $2.5 \mathrm{~g} \mathrm{~m}^{-2} \mathrm{~d}^{-1}$, removal rates remained relatively stable, indicating that the largescale wetland system was effectively removing organic matter. When input loading rate of $\mathrm{NH}_{4}^{+}-$ $\mathrm{N}$ was less than $0.3 \mathrm{~g} \mathrm{~m}^{-2} \mathrm{~d}^{-1}, \mathrm{NH}_{4}{ }^{+}-\mathrm{N}$ removal rate was relatively low but stable. On the other hand, when the inflow loading exceeded the optimum range, the variability of COD and $\mathrm{NH}_{4}{ }^{+}-\mathrm{N}$ removal increased, resulting in the system performance unpredictable. During the period of this full-scale study, inflow loadings might be greatly increased as a result of the increased precipitation (observed in warm seasons) and groundwater or raw wastewater discharge to the CW system (occurred in cold seasons), which would bring about in relatively lower pollutants removal rates. On the whole, the results in this study can be consistent with previous research which indicated that increase of input loading would coincide with higher removal rates, but a low or too high hydraulic load could be not a favorable condition for the removal processes (Saeed and Sun, 2011; Jia et al., 2014; Saeed and Sun, 2012). Typically, the authors believe that the maximum influent loads of $2.5 \mathrm{~g} \mathrm{~m}^{-2} \mathrm{~d}^{-1}$ for COD and $0.3 \mathrm{~g} \mathrm{~m}^{-2} \mathrm{~d}^{-1}$ for $\mathrm{NH}_{4}^{+}-\mathrm{N}$ could be suitable for designing the large-scale multi-stage SF CW system.

\section{Conclusions}

In this case study it was shown that a good long-term water quality improvement was achieved in a large-scale multi-stage SF CW system fed with secondary effluents from the WWTPs in northern China. The average effluent COD and $\mathrm{NH}_{4}{ }^{+}-\mathrm{N}$ concentration in the $\mathrm{Wu}$ River large-scale $\mathrm{CW}$ can apparently comply with the Grade III of Environmental Quality Standards for Surface Water in 
China. The average removal efficiency of $\mathrm{COD}$ and $\mathrm{NH}_{4}{ }^{+}-\mathrm{N}$ could reach $53 \%$ and $72 \%$, respectively. Nevertheless, the variation of input loading gave a significant effect on the removal rate in the large-scale CW system.
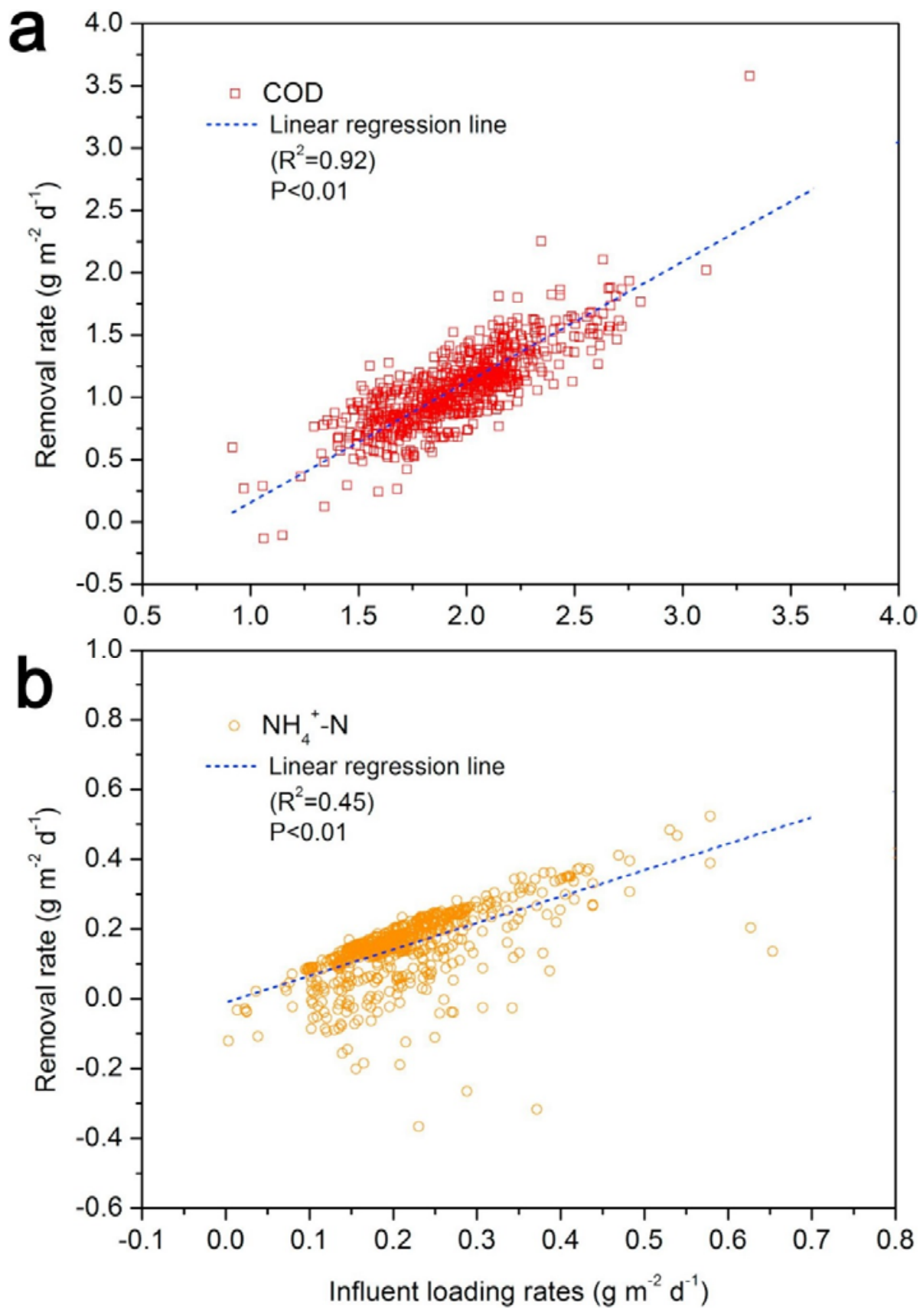

Fig. 2. Effect of inflow loading rate on removal rate of COD and $\mathrm{NH}_{4}{ }^{+}-\mathrm{N}$ in the Wu River multistage constructed wetland. $\mathrm{R}^{2}$ represents the coefficient of determination of the linear or polynomial model between inflow loading rate and removal rate of COD and $\mathrm{NH}_{4}{ }^{+}-\mathrm{N}$.

\section{Acknowledgements}

We gratefully acknowledge financial support by the Water Resources Science and Technology Program of Shaanxi Province (2017slkj-6), the National Science Foundation of China (NSFC, 
Project No. 51508466, 21507072), and the Natural Science Basic Research Plan in Shaanxi Province of China (2017JQ4024).

\section{Appendix A. Supplementary material}

Supplementary data associated with this article can be found, in the online version, at https://doi.org/10.1016/j.biortech.2017.10.099.

\section{References}

APHA, 2005. Standard Methods for the Examinations of Water and Wastewater, 21st ed. APHA and AWWA and WEF, DC Washington.

Andreo-Martínez, P., García-Martínez, N., Quesada-Medina, J., Almela, L., 2017. Domestic wastewaters reuse reclaimed by an improved horizontal subsurface-flow constructed wetland: a case study in the southeast of Spain. Bioresour. Technol. 233, 236 - 246.

Avila, C., Bayona, J.M., Martín, I., Salas, J.J., García, J., 2015. Emerging organic contaminant removal in a full-scale hybrid constructed wetland system for wastewater treatment and reuse. Ecol. Eng. $80,108-116$.

Barco, A., Borin, M., 2017. Treatment performance and macrophytes growth in a restored hybrid constructed wetland for municipal wastewater treatment. Ecol. Eng. 107, 160 - 171.

Chen, Y., Wen, Y., Tang, Z., Li, L., Cai, Y., Zhou, Q., 2014. Removal processes of disinfection byproducts in subsurface-flow constructed wetlands treating secondary effluent. Water Res. 51, $163-171$.

Fan, J., Zhang, B., Zhang, J., Ngo, H.H., Guo, W., Liu, F., Guo, Y., Wu, H., 2013. Intermittent aeration strategy to enhance organics and nitrogen removal in subsurface flow constructed wetlands. Bioresour. Technol. 141, 122 - 171.

He, S., Xue, G., 2010. Algal-based immobilization process to treat the effluent from a secondary wastewater treatment plant (WWTP). J. Hazard. Mater. 178, 895 - 899.

Jia, H., Sun, Z., Li, G., 2014. A four-stage constructed wetland system for treating polluted water from an urban river. Ecol. Eng. 71, 48 - 55.

Li, Y.D., Chen, Y., Wang, L., Yao, L., Pan, X.M., Lee, D.J., 2017. Pollution tolerant protozoa in polluted wetland. Bioresour. Technol. 240, 115 - 122.

Matamoros, V., García, J., Bayona, J.M., 2008. Organic micropollutant removal in a fullscale surface flow constructed wetland fed with secondary effluent. Water Res. 42, 653- 660.

Rai, U.N., Tripathi, R.D., Singh, N.K., Upadhyay, A.K., Dwivedi, S., Shukla, M.K., Mallick, S., Singh, S.N., Nautiyal, C.S., 2013. Constructed wetland as an ecotechnological tool for pollution treatment for conservation of Ganga river. Bioresour. Technol. 148, 535 - 541.

Saeed, T., Sun, G., 2011. The removal of nitrogen and organics in vertical flow wetland reactors: predictive models. Bioresour. Technol. 102, 1205 - 1213.

Saeed, T., Sun, G., 2012. A review on nitrogen and organics removal mechanisms in subsurface flow constructed wetlands: dependency on environmental parameters, operating conditions and supporting media. J. Environ. Manage. 112, 429 - 448. 
Verlicchi, P., Zambello, E., 2014. How efficient are constructed wetlands in removing pharmaceuticals from untreated and treated urban wastewaters? A review. Sci. Total Environ. 470 - 471, 1281 1306.

Vivant, A.L., Boutin, C., Prost-Boucle, S., Papias, S., Hartmann, A., Depret, G., Ziebal, C., Le Roux, S., Pourcher, A.M., 2016. Free water surface constructed wetlands limit the dissemination of extended-spectrum beta-lactamase producing Escherichia coli in the natural environment. Water Res. 104, 178 - 188.

Wang, W., Gao, J., Guo, X., Li, W., Tian, X., Zhang, R., 2012. Long-term effects and performance of two-stage baffled surface flow constructed wetland treating polluted river. Ecol. Eng. 49, 93 - 103.

Wu, S., Carvalho, P.N., Müller, J.A., Manoj, V.R., Dong, R., 2016a. Sanitation in constructed wetlands: a review on the removal of human pathogens and fecal indicators. Sci. Total Environ. 541, 8 - 22.

Wu, H., Fan, J., Zhang, J., Ngo, H., Guo, W., Liang, S., Lv, J., Hu, Z., Lu, S., Wu, W., Wu, S., $2016 b$. Intensified organics and nitrogen removal in the intermittent aerated constructed wetland using a novel sludge-ceramsite as substrate. Bioresour. Technol. 210, $101-107$.

Wu, H., Lin, L., Zhang, J., Guo, W., Liang, S., Liu, H., 2016c. Purification ability and carbon dioxide flux from surface flow constructed wetlands treating sewage treatment plant effluent. Bioresour. Technol. 219, $768-772$.

Wu, H., Zhang, J., Ngo, H.H., Guo, W., Hu, Z., Liang, S., Fan, J., Liu, H., 2015a. A review on the sustainability of constructed wetlands for wastewater treatment: design and operation. Bioresour. Technol. 175, $594-601$.

Wu, H., Fan, J., Zhang, J., Ngo, H., Guo, W., Liang, S., Hu, Z., Liu, H., 2015b. Strategies and techniques to enhance constructed wetland performance for sustainable wastewater treatment. Environ. Sci. Pollut. Res. 22, 14637 - 14650.

Zhang, J., Sun, H., Wang, W., Hu, Z., Yin, X., Ngo, H.H., Guo, W., Fan, J., 2017. Enhancement of surface flow constructed wetlands performance at low temperature through seasonal plant collocation. Bioresour. Technol. 224, 222 - 228. 